\title{
Numerical Analysis of Three-Dimensional Infiltration in a Municipal Solid Waste Landfill under Rainfall
}

\author{
Rong Yang ${ }^{1}$, Zengguang $\mathrm{Xu}^{1^{*}}$, Junrui Chai ${ }^{1,2^{* *}}$ \\ ${ }^{1}$ State Key Laboratory of Eco-hydraulics in Northwest Arid Region of China, Xi'an University of Technology, \\ Shaanxi, China \\ ${ }^{2}$ School of Civil Engineering, Xijing University, Xi'an, China
}

Received: 30 April 2019

Accepted: 6 June 2019

\begin{abstract}
High leachate levels seriously affect slope stability in landfills. Heavy rainfall and degradation of waste are the main causes of high leachate levels. Here, we analyze rainfall patterns, simulate leachate levels, and suggest methods for reducing the impact of heavy rain on slope stability. Heterogeneous characteristics of waste piles are simulated by combining a user subroutine with the finite element method. Finally, under maximum daily rainfall conditions at the landfill, seepage is simulated in three dimensions. We find that heterogeneities in hydraulic conductivity are often responsible for perched leachate levels. For a given rainfall, the leachates are perched in multiple places with the least rainfall duration; for a given rainfall duration, the leachates are perched in multiple places with the greatest rainfall intensity. High leachate levels exist downstream of the landfill slope and they dissipate slowly. From the initial rainfall to 2.8 hours after the rain, more saturated zones exist in the simulated landfill, especially near landfill slopes. In order to stabilize landfills for safety, we suggest the use of drainage measures, including silo systems, at the top of the waste pile and near slopes in order to reduce leachate levels.
\end{abstract}

Keywords: municipal solid waste landfill, rainfall; heterogeneity model, three-dimensional, seepage analysis

\section{Introduction}

Due to the rapidly increasing production of municipal solid waste (MSW) in China, the development of safe and stable landfills is critical for the protection of lives and property. According to statistics and analyses

\footnotetext{
*e-mail: xuzengguang@xaut.edu.cn
}

**e-mail: jrchai@xaut.edu.cn of multiple landfill accidents across the world, high leachate levels are one of the main factors causing landfill instability [1-3]. Seismic action and adverse waste characteristics are often contributing factors [4-7].

The distribution of leachate has been studied by many scholars around the world. MSW hydraulic conductivities and density have a great influence on leachate distribution, which are typically measured with laboratory tests and field tests [8-10]. Wang et al. (2003) 
considered the heterogeneity of MSW and established a mathematical model of saturated-unsaturated seepage flow, and then analyzed water migration in the landfill [11]. Zhang et al. (2007) analyzed the saturated-unsaturated seepage of landfills, established the two-dimensional seepage control equation for the waste element, and studied the growth law describing leachate levels in the guide layer [12]. The saturated hydraulic conductivity and soil-water characteristic curve (SWCC) of the MSW were measured in laboratory tests. Finally, the permeability function was derived and landfill stability was calculated in the situations of effective intermediate layers and invalid intercepting flood channels [13]. Zhang et al. (2013) measured the saturated hydraulic conductivities of MSW in different depths and conducted seepage analysis of the landfill in consideration of the high leachate mound [14]. Anderson et al. (2015) designed a small desktop centrifuge to measure permeability [15]. The landfill was divided into many areas and they were set different characteristic values, although many researches, and it has diversity compared with reality considering the MSW heterogeneity.

Jang et al. (2002) measured hydraulic properties in laboratory tests and examined changes in leachate levels with compaction and changes in covering thickness [16]. Xu et al. (2013) researched the key position of the leachate overflow point and proposed measures to reduce the seepage of leachate and improve the stability of the landfill [17]. The relationships between landfilled MSW characteristics and buried depth were analyzed, and the seepage and stability of the landfill were simulated by two-dimensional numerical simulation [2]. In addition, MSW density has great influence on hydraulic conductivities [18-20]. Through the engineering geological analysis on unstable landfills, researchers have found that the main factors influencing stability are rainfall, earthquakes, and the human element [21]. Dai et al. (2016) simulated flow failure of an MSW landfill using a series tests and predicted the flow depth and the maximum speed [22]. Yin et al. (2016) analyzed factors related to the landfill landslide that occurred in Shenzhen, China on December 20, 2015, including landfill composition, rainfall, and mechanical parameters [23]. Considering the composition and compaction of landfilled MSW, Ali et al. (2017) performed a back analysis on the slope stability of landfill using the probability method and gave probability distributions of engineering properties, including density, cohesion, and the friction angle [24]. Through the work by Nadukuru et al. (2017) and Feng et al. (2016), we know that the cover system also affects the seepage and slope stability of landfill [25-26]. There are obvious seasonal differences in climate in Shaanxi Province, especially in the summer. Rainfall is the main factor that can cause a sharp rise in the leachate levels. Although many workers have analyzed seepage of landfill, three-dimensional seepage has not been extensively studied.
Based on the above research, several factors, such as rainfall, heterogeneity characteristics of MSW and three-dimensional seepage are considered in the analysis of three-dimensional seepage in an MSW landfill in Xi'an, Shaanxi Province, and the implications for landfill stability. After performing numerical calculations, we verify the accuracy of the seepage model. Our results provide a strong foundation for the safe operation of a landfill during rainfall.

\section{Material and Methods}

\section{Seepage Theory of Landfill}

There are two seepage patterns in the landfill: Darcy flow and dominant flow. Due to complexities in composition, high porosity, high compressibility, and degradability, Darcy flow is the main motion type in landfills. In Darcy flow, the seepage velocity is proportional to the hydraulic gradient (Eq. 1), and the water flows along a large, curved pore channel. Currently there are no good ways to simulate the dominant flow due to the complex composition of MSW [27]. In old landfills, the pore channels in the landfill are very tortuous and small, resulting in a reduction in dominant flow. Thus, seepage in these old landfills tends to be more consistent with Darcy's Law [28]. In this paper, seepage flow is considered as a saturated transient seepage problem. During the process of seepage, the matrix suction and pore water pressure change over time.

Darcy's Law is:

$$
v=k i
$$

... and the seepage continuity equation can be written as follows:

$$
\frac{\partial v_{x}}{\partial x}+\frac{\partial v_{y}}{\partial y}+\frac{\partial v_{z}}{\partial z}+Q=\frac{\partial \theta}{\partial t}
$$

Therefore:

$$
\frac{\partial}{\partial x}\left(k_{x} \frac{\partial h}{\partial x}\right)+\frac{\partial}{\partial y}\left(k_{y} \frac{\partial h}{\partial y}\right)+\frac{\partial}{\partial z}\left(k_{z} \frac{\partial h}{\partial z}\right)+Q=\frac{\partial \theta}{\partial t}
$$

...where $v$ is flow velocity; $v_{x}, v_{y}$, and $v_{z}$ are seepage velocities along the $x, y$, and $z$ directions; $k$ is hydraulic conductivity; $k_{x}, k_{y}$ and $k_{z}$ are hydraulic conductivities along the $x, y$ and $z$ directions; $i$ is the total hydraulic gradient; $Q$ is the flow condition; $\theta$ is the volumetric water content, and considering the saturated seepage the value of $\theta$ is 0 ; and $t$ is time.

The boundary conditions of seepage flow usually include three types: given head, flow, and mixed boundaries. 


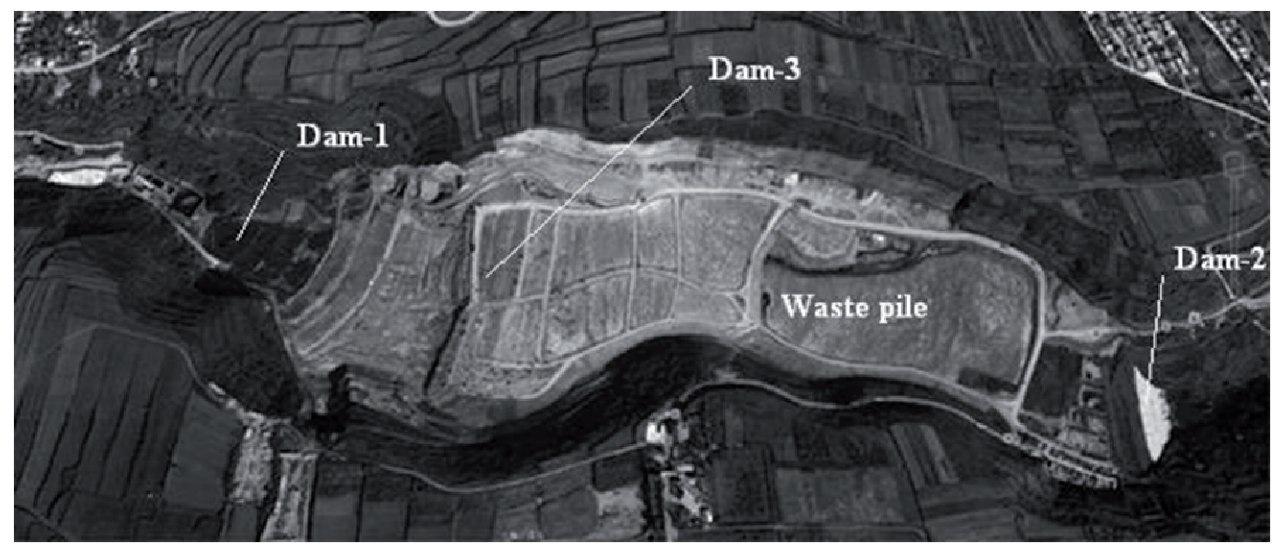

Fig. 1. Satellite image of the landfill.

\section{Landfill Present Situation}

The landfill is in Xi'an and it belongs to the valley landfill. The main sources of landfilled MSW are domestic waste, road cleaning waste, and commercial waste. The landfill was constructed in 1993 and formally put into service in June 1994. From 1994 to 2017, the daily processing capacity grew from $1260 \mathrm{t}$ to more than $10000 \mathrm{t}$. The landfill covers an area of $11 \mathrm{~km}^{2}$ and its design height is $130 \mathrm{~m}$. At present, the landfill has been piled up to $120 \mathrm{~m}$ and is facing closure. A satellite image of the landfill is shown in Fig. 1. Dam 1 is a waste dam at a downstream location, used to block MSW and to form the initial landfill capacity. Dam 2, located at an upstream location, is used to prevent flooding. Dam 3, built in 2014, is located at the top of an $80 \mathrm{~m}$ waste pile, and is used to form the landfill capacity.

\section{Hidden dangers}

Due to its large scale, high pile height, and high initial moisture content of the landfill, blockage of the drainage layer and continuous rainfall bot pose safety hazards. With the continuous degradation of MSW, the porosity of the landfill has decreased over time, leading to a reduction in the maximum rate of leachate discharge. This has resulted in high leachate levels and slope instability. During operation, multiple leachates in the upper region and downstream of the slope overflowed, resulting in a higher stagnant water level. The upstream dam (Dam 2) collapsed in 2000, and it was strengthened with dry masonry on the slope in 2001. Due to the high leachate level in the waste pile and the uneven settlement of the MSW, leachate leakage and cracking of the dam body still pose risks.

During heavy rain in 2007, local instability slip occurred in the downstream slope of the landfill and the downstream dam (Dam 1) collapsed due to excessive water pressure. In response, the slope ratio was adjusted from 1:2 to 1:3, and the slope was strengthened. In October 2017, during continuous rainfall, the landfill leachate level is too high and overflowing. These episodes reinforce the notion that it is urgent to study the seepage field during continuous rainfall and to ensure safe operation of the landfill. Field investigation figures of the landfill are presented in Fig. 2a) and (b) when it is $80 \mathrm{~m}$ high (in winter) and $120 \mathrm{~m}$ high (in summer). The rainfall in winter is very light, whereas in the summer it is heavier, resulting in obvious differences in leachate levels.

\section{Leachate Sources}

The sources of landfill leachate are rainfall, waste water, water produced by degradation, surface water,

a)

b)
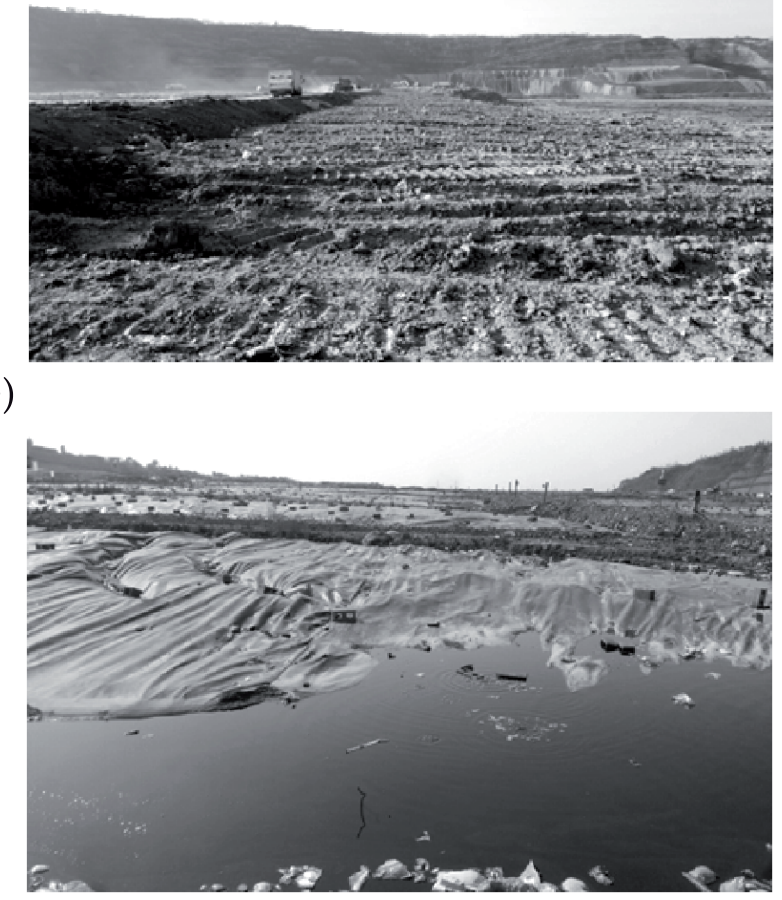

Fig. 2. Field investigation figures of the landfill: a) in December 2013 and b) in May 2017. 


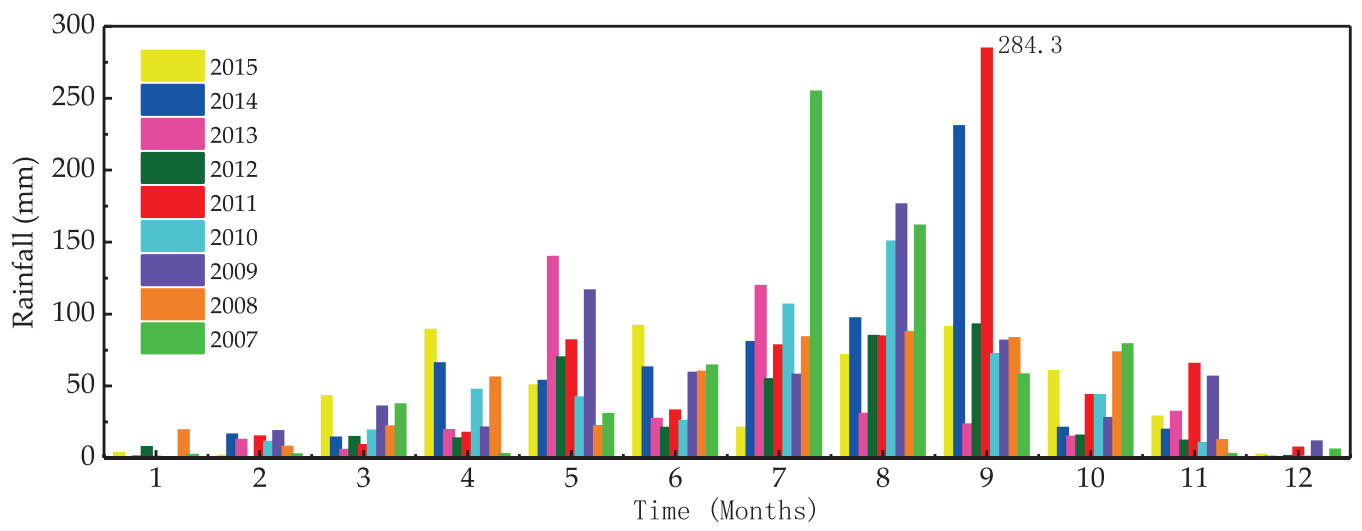

Fig. 3. Statistical data of rainfall from 2007 to 2015 in Xi'an [32].

and groundwater. Landfills are usually built above the water table and surrounded by an impermeable system at the bottom and sides. The waste has high water content because of the large amount of kitchen waste in China. The landfill is in the loess tableland, which belongs to the valley landfill. The surface water in the area is dominated by gully ponds. The water of the ponds exists all year round and the variation of water level is about 2-3 m. No obvious surface flow is found, and the water depth is about $2.5 \mathrm{~m}$ during the survey period. In this paper the only resource of the rain is considered in seepage analysis. When considering all the resources of leachate, the model will be very complex. The internal intermediate layers were ignored and the drain was choked completely when analyzing seepage in the landfill.

\section{Rainfall of Xi'an}

Xi'an has a semi-humid monsoon climate with four distinct seasons. Average annual rainfall values for the past nine years were $385.3 \mathrm{~mm}$ (2012)-717.8 mm (2011); the average number of rainy days per year was 96.6. Every year there are three peak periods of rainfall: from May to June (the spring), from July to August (the summer), and from September to October (the autumn). The average monthly rainfall in Xi'an according to meteorological statistics is shown in Fig. 3, and the daily rainfall of Xi'an is shown in Fig. 4 [29-30]. During 9 years, the maximum monthly rainfall is $284.3 \mathrm{~mm}$, and it occurred in September 2011. Through the investigation the average rain days are 10 days in September. Thus, the average daily rainfall is $28.4 \mathrm{~mm} / \mathrm{d}$. On October 3, 2017 the maximum daily rainfall was $57.0 \mathrm{~mm} / \mathrm{d}$, and On July 25, 2016 the maximum daily rainfall was $45.7 \mathrm{~mm} / \mathrm{d}$. Three-Dimensional Seepage Analysis on Municipal
Solid Waste Landfill

\section{Model and Boundary Conditions}

The numerical model of the landfill was established according to geological prospecting data, and it is meshed by tetrahedral solid elements (106749 elements and 20185 nodes). The landfill model and its elements are shown in Figs 5-7. The landfill is established from downstream to upstream by layer compaction

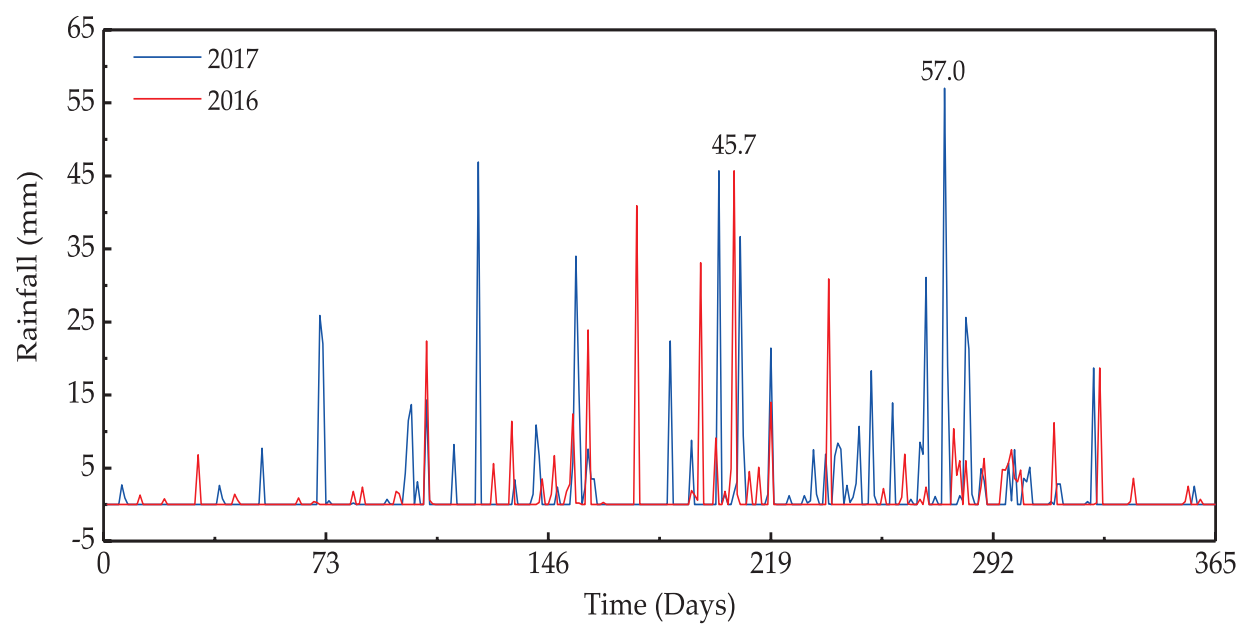

Fig. 4. Actual value of daily rainfall of Xi'an in 2016-2017 [33]. 


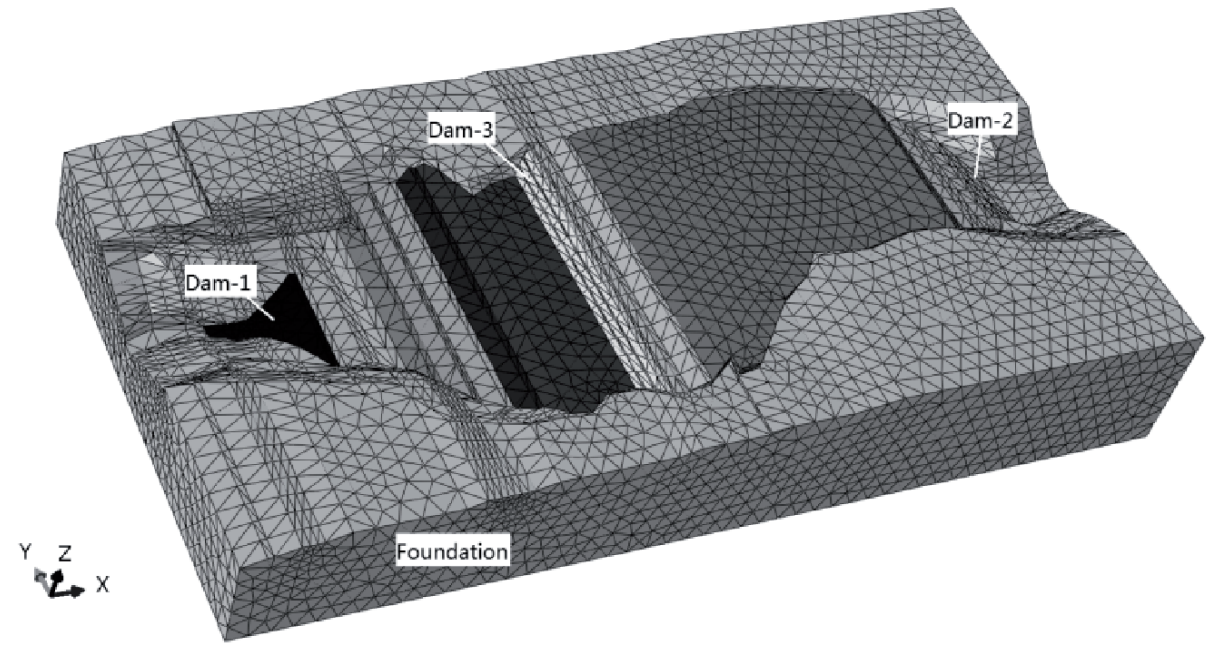

Fig. 5. Model and mesh of landfill.

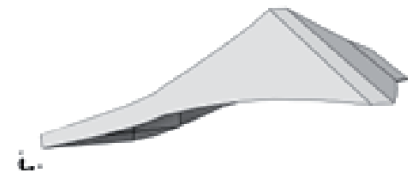

Dam-1

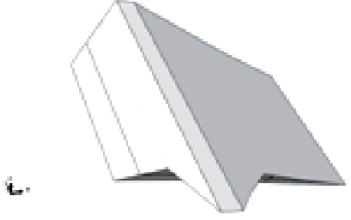

Dam-2

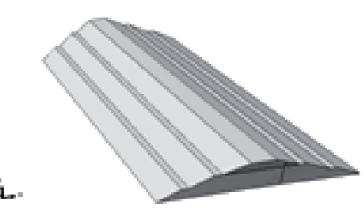

Dam-3

Fig. 6. Models of retaining dams.

technology. The landfill has 12 layers (each one $10 \mathrm{~m}$ thick). The top elevation and bottom elevation of the waste pile are $660 \mathrm{~m}$ and $540 \mathrm{~m}$, respectively.

There is a pond upstream of the landfill, which has water all year round and is about $3 \mathrm{~m}$ deep. We take the elevation of the base of Dam 1 as the water head in the downstream region. Therefore, constant heads of $593 \mathrm{~m}$ and $495 \mathrm{~m}$ are added to the landfill upstream and
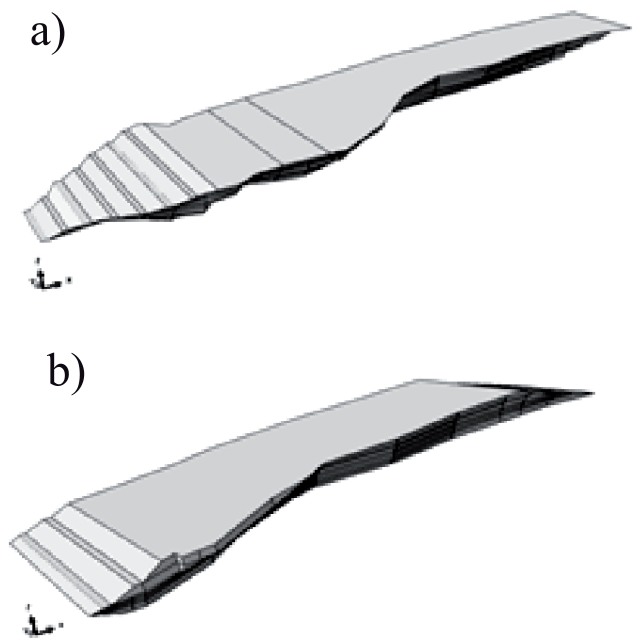

Fig. 7. Models of waste pile: a) $0-80 \mathrm{~m}$ and b) $80-120 \mathrm{~m}$. downstream, respectively. The average rainfall intensity in the horizontal plane is applied on the top part of the landfill, and the average rainfall intensity in the landfill slope is applied based on slope.

\section{Landfill Properties}

The material properties of landfill in various regions are shown in Table 2. According to research data [2, 31], we developed a fitting equation for density and burying depth (Eq. 4) and a fitting equation for saturated hydraulic conductivity and burying depth (Eq. 5).

The fitting equation:

$\rho=8.286 \times 10^{-1}+2.313 \times 10^{-2} H-3.700 \times 10^{-4} H^{2}+2.263 \times 10^{-6} H^{3}$

$\lg k_{\text {sat }}=-4.024-1.018 \times 10^{-1} \mathrm{H}-2.815 \times 10^{-5} \mathrm{H}^{2}+7.077 \times 10^{-6} \mathrm{H}^{3}$

...where is the depth of waste pile, and the unit is $m$.

By dint of the user subroutine interface of ABAQUS [32], heterogenous characteristic simulation of the waste pile was implemented by user-defined subroutine. The distributions of the density and saturated hydraulic conductivity in the waste pile for section $\mathrm{Y}=500 \mathrm{~m}$ are shown in Figs 8 and 9, respectively. 
Table 1. Properties of landfills in various regions.

\begin{tabular}{|c|c|c|c|c|}
\hline MSW characteristic & Dam 1,2,3 & Foundation & $\begin{array}{c}\text { Waste pile } \\
(H>60 \mathrm{~m})\end{array}$ & $\begin{array}{c}\text { Waste pile } \\
(H=0-60 \mathrm{~m})\end{array}$ \\
\hline Density $\left(\mathrm{kg} / \mathrm{m}^{3}\right)$ & 1.90 & 1.90 & 1.37 & $(4)$ \\
\hline Saturated hydraulic conductivity $(\mathrm{m} / \mathrm{s})$ & $1.0 \times 10^{-7}$ & $1.0 \times 10^{-7}$ & $2.03 \times 10^{-9}$ & $(5)$ \\
\hline
\end{tabular}

Table 2. Calculation schemes for rainfall at different times.

\begin{tabular}{|c|c|c|c|}
\hline Scheme & $\begin{array}{c}\text { Rainfall duration } \\
(\mathrm{s})\end{array}$ & $\begin{array}{c}\text { Average rainfall intensity in horizontal plane of waste pile } \\
(\mathrm{m} / \mathrm{s})\end{array}$ & $\begin{array}{c}\text { Maximum daily rainfall } \\
(\mathrm{mm})\end{array}$ \\
\hline Scheme 1 & $0-28800$ & $4.80 \times 10^{-7}$ & $57.0(2017.10 .3)$ \\
\hline Scheme 2 & $0-14400$ & $9.50 \times 10^{-7}$ & $57.0(2017.10 .3)$ \\
\hline Scheme 3 & $0-3600$ & $3.80 \times 10^{-6}$ & $57.0(2017.10 .3)$ \\
\hline Scheme 4 & $0-3600$ & $3.05 \times 10^{-6}$ & $45.7(2016.7 .25)$ \\
\hline Scheme 5 & $0-3600$ & $1.89 \times 10^{-6}$ & $28.4(2011.9)$ \\
\hline
\end{tabular}

\section{Calculation Schemes}

The data from Fig. 5 indicate that the maximum daily rainfall appears on October 3, 2017. Based on the numerical simulation software, the seepage field of the landfill under the action of the rainfall is simulated. Considering the duration of rain fall and rainfall intensity, transient seepage analysis is conducted at 5 calculation schemes. According to the related literature, the rainfall infiltration coefficients of the waste pile and retaining dams are 0.24 and 0.23 , respectively [33]. In the calculation process, we assume that all the schemes start at a time of $0 \mathrm{~s}$ (shown in Table 2).

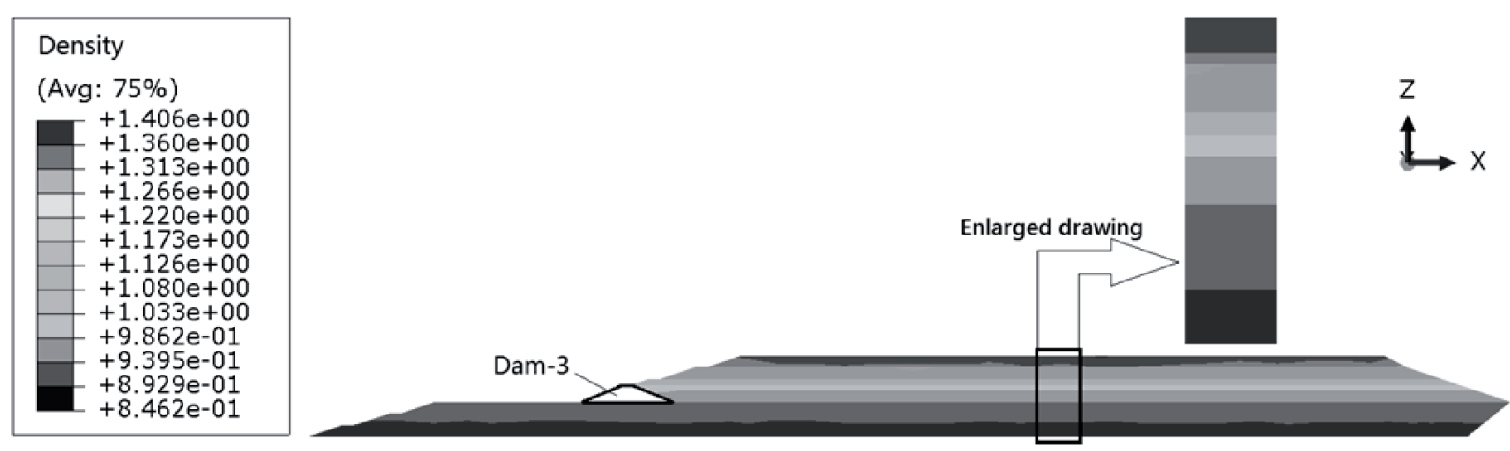

Fig. 8. Distribution of density $\left(\mathrm{kg} / \mathrm{m}^{3}\right)$ in the waste pile $(H=0-60 \mathrm{~m})$.

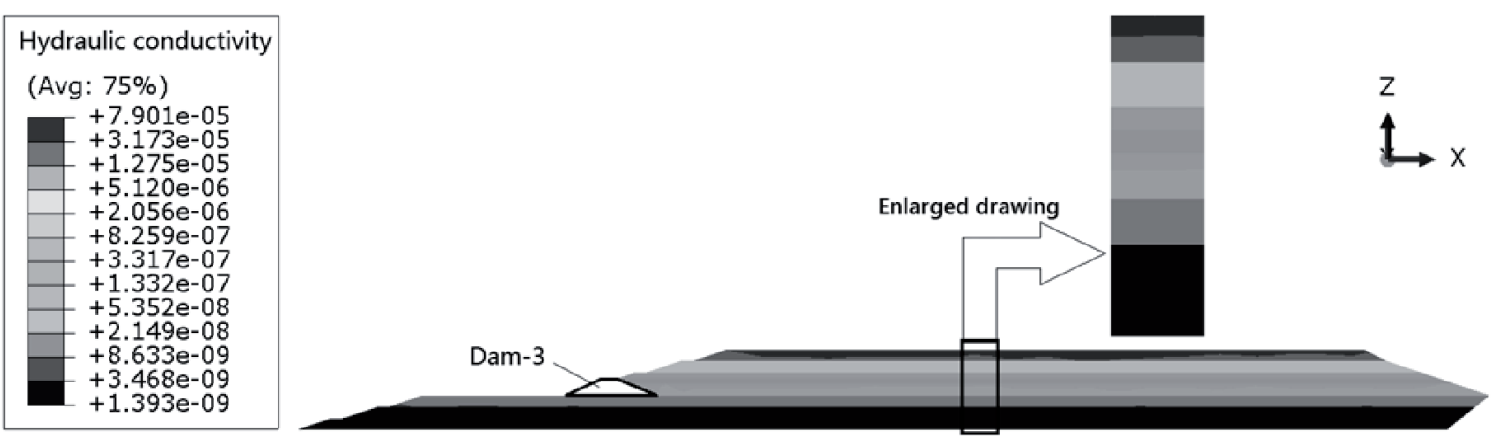

Fig. 9. Distribution of saturated hydraulic conductivity $(\mathrm{m} / \mathrm{s})$ in the waste pile $(H=0-60 \mathrm{~m})$. 
Table 3. Initial times of saturation and maximum pore pressures in the landfill.

\begin{tabular}{|c|c|c|c|c|}
\hline \multirow{2}{*}{ Scheme } & \multicolumn{2}{|c|}{ The initial appearing moment of saturated area (s) } & Maximum pore pressure (Pa) \\
& Landfill slope surface & Waste pile surface at the 12 $2^{\text {th }}$ layer & Waste pile interior & $2270(\mathrm{~A})$ \\
\hline Scheme 1 & 2463 & 6486 & 5115 & $3286(\mathrm{~B})$ \\
\hline Scheme 2 & 1209 & 2085 & 1769 & $5272(\mathrm{C})$ \\
\hline Scheme 3 & 280 & 444 & 384 & $3874(\mathrm{D})$ \\
\hline Scheme 4 & 350 & 626 & 545 & $2289(\mathrm{E})$ \\
\hline Scheme 5 & 650 & 960 & 807 & \\
\hline
\end{tabular}

\section{Results and Discussion}

\section{Appearance Position and Sequence of the Leachate Level}

For section $\mathrm{Y}=495 \mathrm{~m}$, Table 3 shows the initial appearing moment of saturated area and the maximum pore pressure in the landfill. Under all of the schemes, saturation first appeared on the landfill slope surface. Only later did it appear in the waste pile interior, followed by the $12^{\text {th }}$ layer of the waste pile surface. This is because landfill slope is affected by rainfall on the slope and the horizontal plane at the same time. Under the same rainfall, the greater the rainfall duration, the longer the initial time of appearance lags among three positions. Under the same rainfall duration, the less the rainfall intensity, the longer the initial appearing time lags among three positions. The maximum pore pressures are all produced at the end of the rainfall; the value under Scheme 3 is the largest. The positions of maximum pore pressures under all the schemes are presented in Fig. 10. We conclude that the maximum pore pressure mainly occurs in the downstream slope of the $3^{\text {rd }}$ waste pile layer and the upstream slope of the 10 th waste pile layer.

The leachate distributions in Scheme 3 are shown in Figs 11-13. When the intermediate layer exists, the landfill has a perched leachate level. Without the

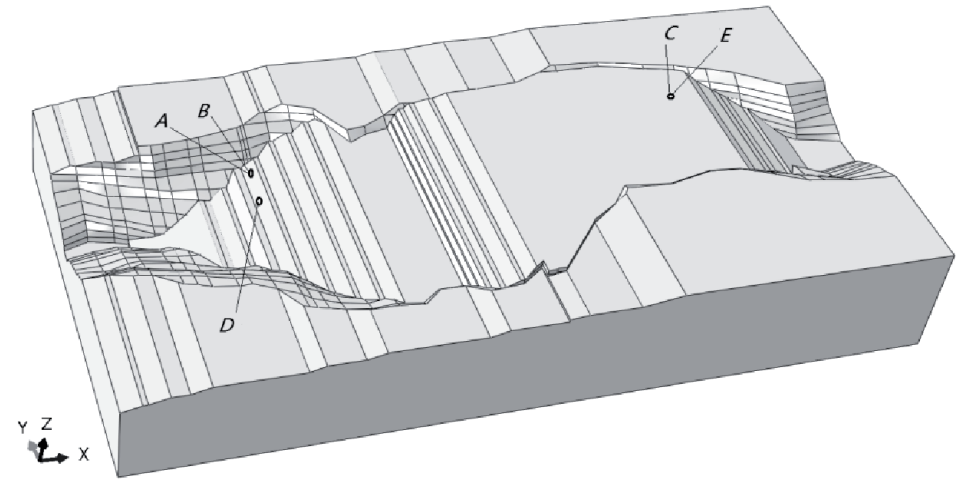

Fig. 10. Positions of maximum pore pressures in Schemes 1-5.

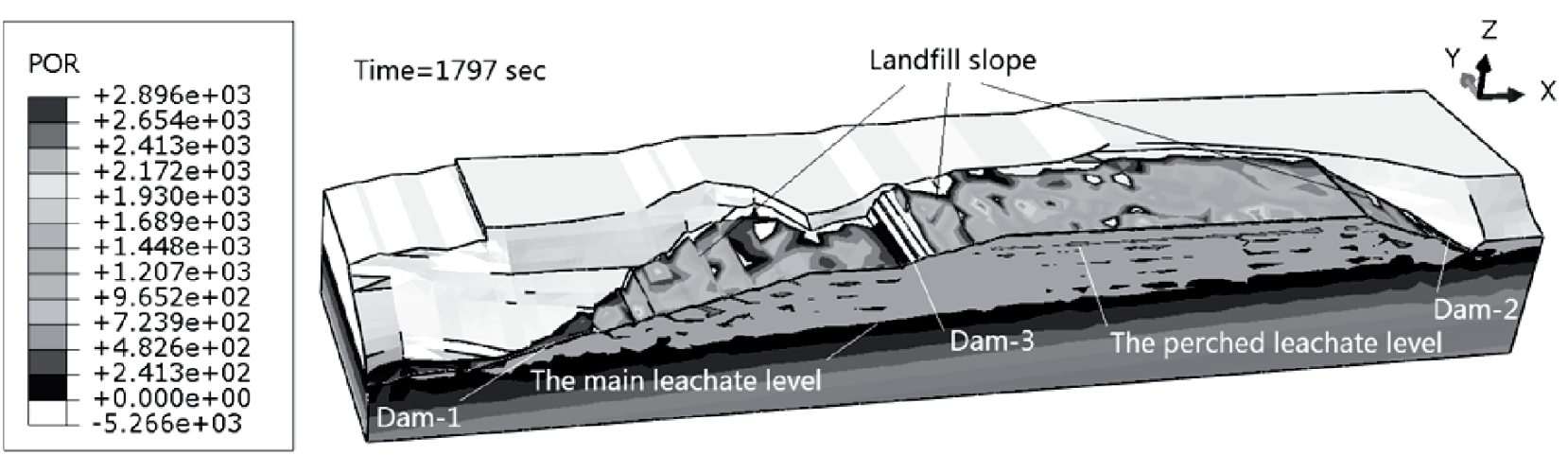

Fig. 11. Leachate level of the landfill for Scheme 3 (rain for half an hour). 

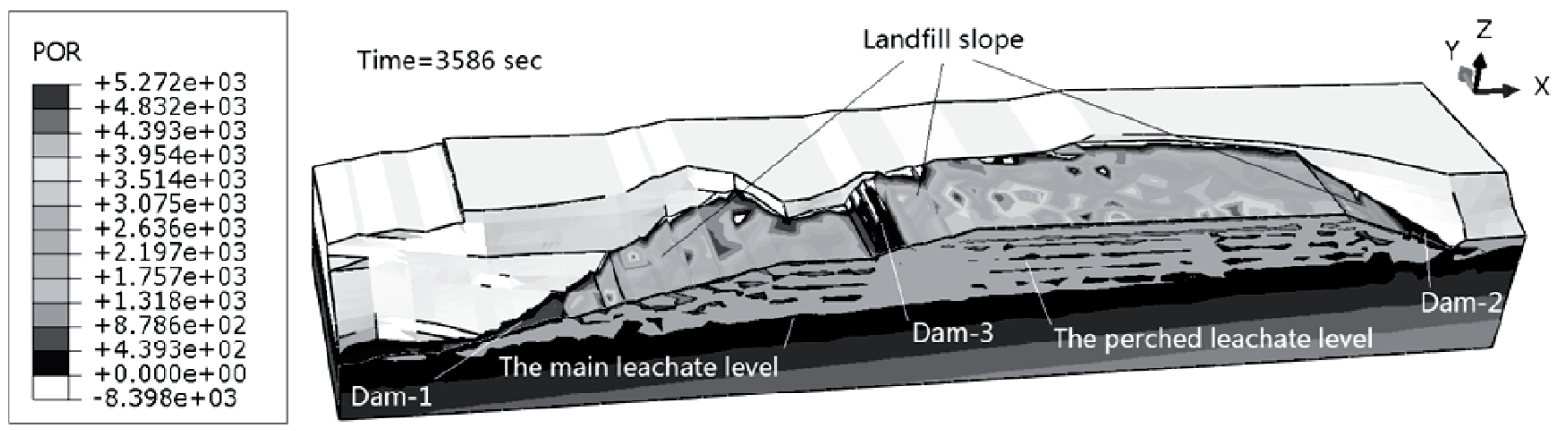

Fig. 12. Leachate level of the landfill for Scheme 3 (rain for an hour).
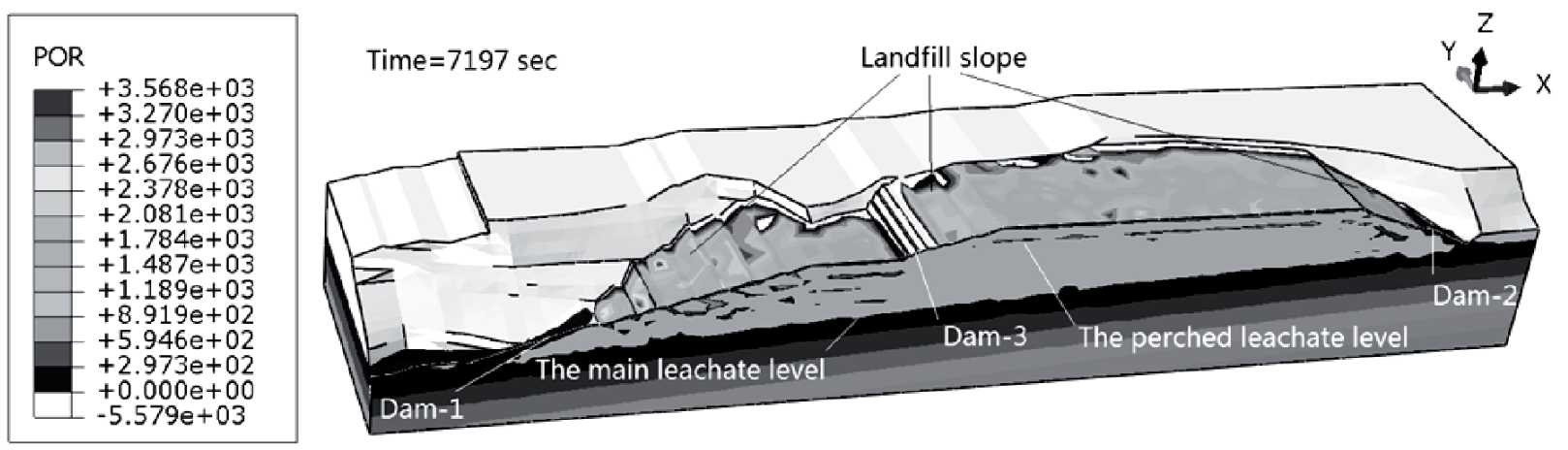

Fig. 13. Leachate level of the landfill for Scheme 3 (an hour after rain stops).

intermediate layer, the landfill also produces perched leachate level. The amount of perched leachate level in this analysis depends on the distribution law of hydraulic conductivity and the rainfall duration. According to the geological survey, there are multiple layers of leachate at the slope of the landfill site. In fact, the perched leachate level is about 2-6 $\mathrm{m}$ in the slope of landfill. Since the water produced by waste degradation is ignored in our paper, the simulated leachate levels are relatively low. But the law of the simulated results are basically similar to actual leachate distribution. The saturation degree of Dam 3 is different under these three moments. Dam 3 reaches saturation eventually and dissipates first. The figures show that the surfaces of Dam 1, Dam 2, the slope, and the waste pile are saturated, and that a saturated zone exists in the landfill slope interior. The slope on the downstream side tends to saturate and damage easily. The leachate seeps into the bank slopes of the foundation, and the main leachate level rises to varying degrees. Seepage treatment at the

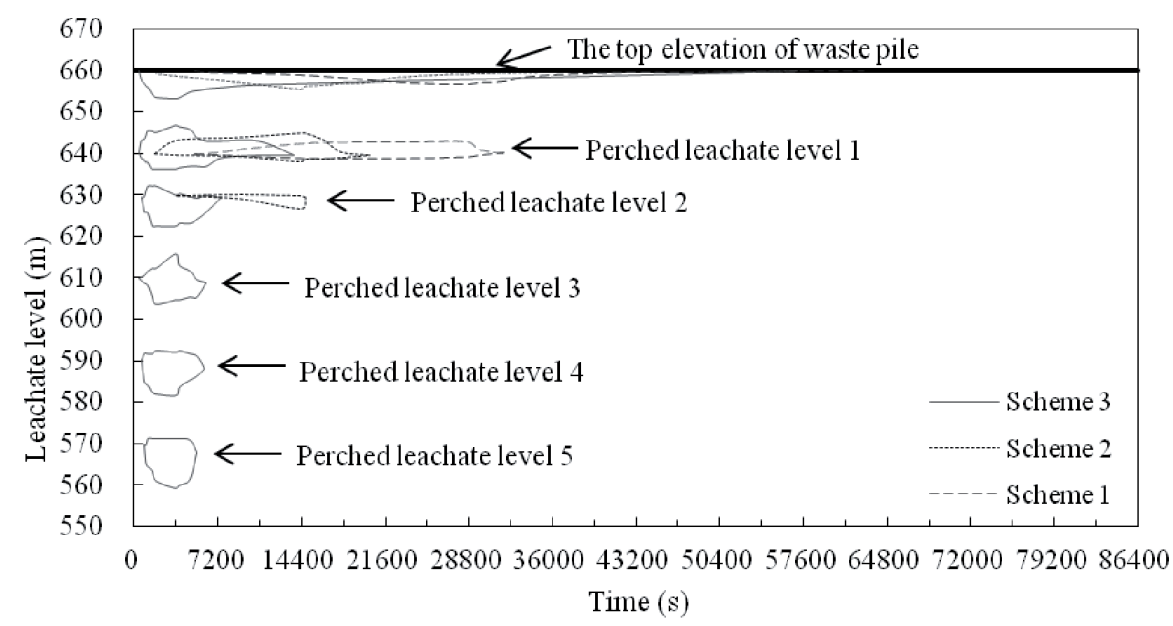

Fig. 14. Leachate levels of the landfill change over time in Scheme 1-3. 


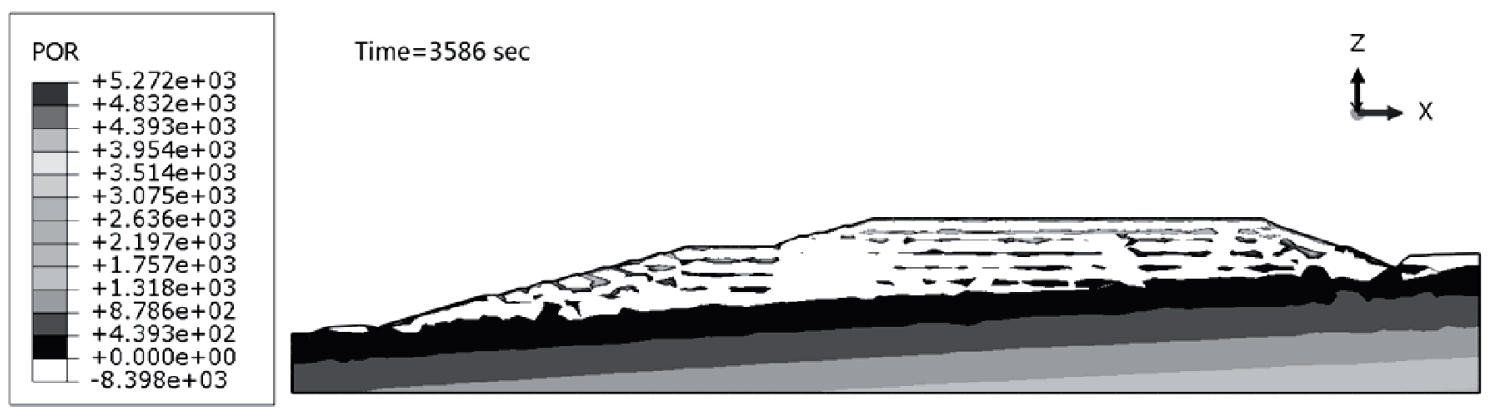

Fig. 15. Leachate level for Scheme 3 at maximum pore pressure.
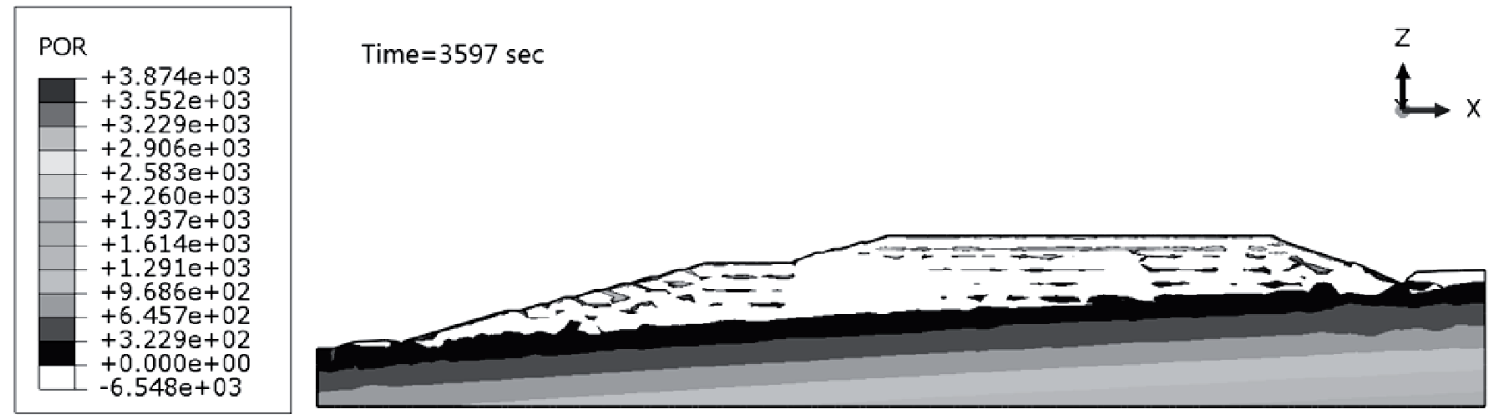

Fig. 16. Leachate level for Scheme 4 at maximum pore pressure.
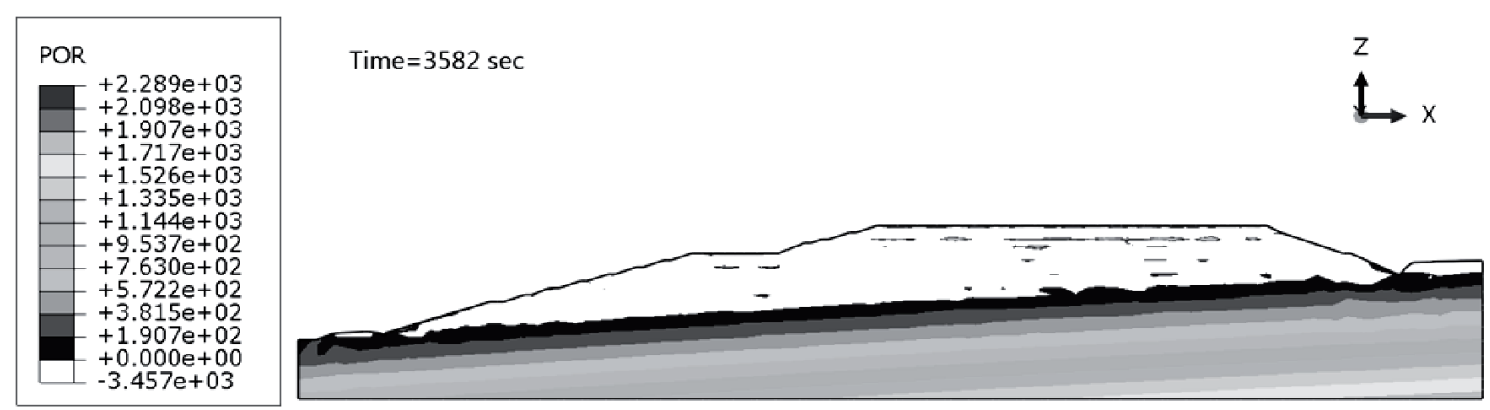

Fig. 17. Leachate level for Scheme 5 at maximum pore pressure.

bank slope can reduce environmental pollution and bank slope destruction in landfills. Thus, seepage control and reinforcement at Dam 1 and Dam 2 are very important. In general, the drains should be embedded during landfill slope construction.

Frequency changes of leachate distribution along with time in Scheme 1-3 are shown in Fig. 14. We can see that leachate levels reach the waste pile surface within 17 hours of the start of rainfall; more perched leachate levels existed during rainfall. After the rain, the perched leachate levels gradually fell. In Scheme 1, only one perched leachate level occurred, at an elevation of $640 \mathrm{~m}$; this was reduced at the end of the rainfall and eventually disappeared after 1 hour. In Scheme 2, perched leachate levels existed at $640 \mathrm{~m}$ and $630 \mathrm{~m}$, perched leachate level 2 disappeared at the end of the rainfall and perched leachate level 1 reduced slowly at the end of the rainfall, eventually disappearing after 1.5 hours. In Scheme 3, perched leachate levels existed at $640 \mathrm{~m}, 630 \mathrm{~m}, 610 \mathrm{~m}, 585 \mathrm{~m}$, and $565 \mathrm{~m}$; perched leachate levels 2-5 were reduced at the end of the rainfall and eventually disappeared after 0.5-1.0 hours. Perched leachate level 1 was reduced slowly at the end of the rainfall and eventually disappeared after 2.8 hours. Perched leachate levels 2-5 dissipated quickly (within an hour); in contrast, the dissipation speed of perched leachate level 1 was relatively slow (1-2.8 hours) and the surface leachate levels dissipated very slowly (over 17 hours). Under a given rainfall rate, the greater the rainfall duration, the faster the dissipation of the perched leachate levels. If the waste water and the water produced by degradation are considered, the leachate level is very high during the rain. 
Leachate Levels for Different Rainfall Intensities

The leachate distributions of landfill in Schemes 3-5 are shown in Figs 15-17 for the time at which the pore pressures were greatest. Under the same rainfall duration, waste pile interiors for Schemes 3-5 have different perched leachate levels. There is almost no leachate under Dam 3 due to its low permeability. The amount of perched leachate level in this analysis depends on the distribution law of hydraulic conductivity and the rainfall intensity. There are more perched leachate levels in Scheme 3. With a decrease in rainfall intensity, the leachate is reduced slowly. In Scheme 5 there was only a small amount of leachate in the landfill.

By analyzing landfill seepage, we can see that drainage needs to be improved; the installation of silo systems at the top of the waste pile may reduce internal levels at times of high rainfall intensity. Considering the landfill security and economic conditions, the positions of chimney drains should be set near the landfill slope.

\section{Conclusions}

Effective leachate distribution is very important for the safety of landfill slopes during the rainy season. Heterogenous characteristics of the waste pile were simulated by combining a user subroutine with the finite element method. Using these outputs, we simulated three-dimensional seepage under the maximum daily rainfall. The results enable us to make several conclusions:

- Variations in hydraulic conductivity and density with depth are set by user subroutine, which allows us to accurately calculate the landfill seepage field.

- Through seepage analysis, we can see that perched leachate levels existed in the landfill; heterogeneities in hydraulic conductivity underlie this phenomenon.

- For a given rainfall, the leachates are perched in multiple places with the least rainfall duration; for a given rainfall duration, the leachates are perched in multiple places with the greatest rainfall intensity.

- When the rainfall has just ended, the landfill experiences the maximum pore pressure and the maximum saturation degree. High perched leachate levels exist in the downstream of landfill slope and they dissipate slowly. From the initial rainfall to 2.8 hours after the rain, pore-saturated zones existed in the landfill - especially near the landfill slope. To achieve the effect of security and stability, we need to take effective measures to reduce perched leachate levels.

\section{Acknowledgements}

This research was funded by the National Natural Science Foundation of China, grant Nos. 51679193, 51679197 and 51922088, and the Special Funds for the
Natural Science Foundation of Shaanxi Province, grant No. 2017JZ013. We would like to thank LetPub (www. letpub.com) for providing linguistic assistance during the preparation of this manuscript.

\section{Conflict of Interest}

The authors declare no conflict of interest.

\section{References}

1. YANG H., XIA J.Y., THOMPSON J.R., FLOWER R.J. Urban construction and demolition waste and landfill failure in Shenzhen, China. Waste Management, 63, 393, 2017.

2. YANG R., XU Z.G., CHAI J.R., QIN Y., LI Y.L. Permeability test and slope stability analysis of municipal solid waste (MSW) in Jiangcungou Landfill, Shaanxi, China. Journal of the Air \& Management Association, 66, 655, 2016.

3. PENG R., HOU Y.J., ZHAN L.T., YAO Y.P. Back-Analyses of Landfill Instability Induced by High Water Level: Case Study of Shenzhen Landfill. International Journal of Environmental Research and Public Health, 13, 126, 2016.

4. FENG S.J., GAO L.Y. Seismic stability analyses for landfill cover systems under different seepage buildup conditions. Environmental Earth Sciences, 66, 381, 2012.

5. FENG, S. J., CHANG, J. Y., CHEN, H. X. Seismic analysis of landfill considering the effect of GM-GCL interface within liner. Soil Dynamics and Earthquake Engineering, 107, 152, 2018.

6. KHOSHAND A., FATHI A., ZOGHI M., KAMALAN H. Seismic stability analyses of reinforced tapered landfill cover systems considering seepage forces. Waste Management \& Research, 36, 361, 2018.

7. ANBAZHAGAN P., SIVAKUMARBABU G.L., LAKSHMIKANTHAN P., VIVEKANAND K. Seimic characterization and dynamic site response of a municipal solid waste landfill in Bangalore, India. Waste Management \& Research, 34, 205, 2016.

8. YANG R., XU Z.G., CHAI J.R. A review of characteristics of landfilled municipal solid waste in several countries: Physical composition, unit weight and permeability coefficient. Polish Journal of Environmental Studies, 27, 2425, 2018.

9. ZENG G., LIU L., XUE Q., WAN Y., MA J., ZHAO Y. Experimental study of the porosity and permeability of municipal solid waste. Environmental Progress and Sustainable Energy, 36, 1694, 2017.

10. KE H., HU J., XU X.B., WANG W.F., CHEN Y.M., ZHAN, L. T. Evolution of saturated hydraulic conductivity with compression and degradation for municipal solid waste. Waste Management, 65, 63, 2017.

11. WANG H.T., YIN Y. Numerical simulation of moisture movement in landfill bioreactors under the condition of leachate recirculation. Environmental Science, 24, 66, 2003 [In Chinese].

12. ZHANG W.J., ZHAN L.T., CHEN Y.M., WEI H.Y. Unsaturated-saturated seepage analysis of municipal solid wastes. Chinese Journal of Rock Mechanics and Engineering, 26, 87, 2007a [In Chinese]. 
13. ZHANG W.J. Experimental and numerical study on water/ leachate transport in landfill of municipal solid waste. $\mathrm{Ph} . \mathrm{D}$. thesis. Zhejiang University, Hangzhou, China, 2007b [In Chinese].

14. ZHANG W.J. Analyses on a high leachate mound in a landfill of municipal solid waste in China. Environmental Earth Sciences, 70, 1747, 2013.

15. ANDERSON C., SIVAKUMAR V., BLACK A. Measurement of permeability using a bench-top centrifuge. Geotechnique, 65, 12, 2015.

16. JANG Y.S., KIM Y.W., LEE S.I. Hydraulic properties and leachate level analysis of Kimpo metropolitan landfill, Korea. Waste Management, 22, 261, 2002.

17. XU Q., POWELL J., TOLAYMAT T., TOWNSEND T.G. Seepage control strategies at bioreactor landfills. Journal of Hazardous, Toxic, and Radioactive Waste, 17, $342,2013$.

18. JIANG G.B., LIU D., CHEN W.M., LI Q.B., LI G.L., QI Y. Impact of landfill density on transport and hydrauliccharacteristics of recirculated leachate. Environmental Technology, 1, 2018.

19. ZHANG Z.Y., WANG Y.F., XU H., FANG Y.H., WU D. $Z$. Influence of effective stress and dry density on the permeability of municipal solid waste. Waste Management \& Research, 36, 471, 2018.

20. JIE Y.X., XU W.J., DUNZHU D.Z., WEI Y.F., PENG T., ZHOU Z.Y. Laboratory testing of a densified municipal solid waste in Beijing. Journal of Central South University. 20, 1953, 2013.

21. HUANG Y., FAN G.B. Engineering geological analysis of municipal solid waste landfill stability. Natural Hazards, 84, 99, 2016.

22. DAI Z.L., HUANG Y., JIANG F.H., HUANG M.S. Modeling the flow behavior of a simulated municipal solid waste. Bulletin of Engineering Geology and the Environment, 75, 275, 2016.

23. YIN Y.P., LI B., WANG W.P., ZHAN L.T., XUE Q., GAO Y., ZHANG N., CHEN H.Q., LIU T.K., LI A.G. Mechanism of the December 2015 Catastrophic Landslide at the Shenzhen Landfill and Controlling Geotechnical Risks of Urbanization. Engineering, 230, 2016.

24. ALI J., BAHRAM G., EDWARD A.M. BRAJESH K.D. Municipal solid waste slope stability modeling: A probabilistic approach. Journal of Geotechnical and Geoenvironmental Engineering, 143, 04017035 (1-10), 2017.

25. NADUKURU S., ZHU M., GOKMEN C., BONAPARTE R. Combined Seepage and Slope Stability Analysis of a Landfill Cover System. Geotechnical Frontiers, GSP 276, 170, 2017.

26. FENG S.J., AI S.G., HUANG R.Q. Stability analysis of landfill cover systems considering reinforcement. Environmental Earth Sciences, 75, 1, 2016.

27. ZEISS C., UGUCCIONI M. Mechanisms and patterns of leachate flow in municipal solid waste landfills. Journal of Environmental Systems, 23, 247, 1994-1995.

28. GRAY W.G., MILLER C.T. On the algebraic and differential forms of Darcy's equation. Journal of Porous Media, 14, 33, 2011.

29. NATIONAL BUREAU OF STATISTICS OF CHINA. China Statistical Yearbook 2008-2016. Beijing: China Statistics Press. 2008-2016. See http://www.stats.gov.cn/ tjsj/ndsj/. [In Chinese]

30. NATIONAL BUREAU OF STATISTICS OF CHINA. China Statistical Yearbook 2017-2018. Beijing: China Statistics Press, 2017-2018. See http://www.stats.gov.cn/ tjsj/ndsj/. [In Chinese].

31. MINISTRY OF HOUSING AND URBAN-RURAL DEVELOPMENT OF THE PEOPLE'S REPUBLIC OF CHINA. Technical code for geotechnical engineering of municipal solid waste sanitary landfill. CJJ176-2012, Beijing, China Construction Industry Press, 2012.

32. ABAQUS 6.14. User subroutines reference guide. Section 1.1.7 (1-3), Section 1.1.32 (1-4). See http:// k6i40obmwiprvot:2080/v6.14/books/sub/default.htm.

33. CHEN Y.F., WANG A.L. Determination of rainfall infiltration coefficient by well data. Ground water, 30, 1, 2008. 
